\title{
KEEFEKTIFAN PEMBELAJARAN BERBANTUAN INTERNET DI SMK SE-KOTA YOGYAKARTA KOMPETENSI KEAHLIAN TEKNIK KOMPUTER DAN JARINGAN
}

\author{
Ganggang Canggi Arnanto \\ Program Studi Pendidikan Teknologi \& Kejuruan PP, UNY \\ canggi.arnanto@gmail.com \\ Mochamad Bruri Triyono \\ Fakultas Teknik Universitas Negeri Yogyakarta \\ bruritriyono@yahoo.co.id
}

\begin{abstract}
Abstrak
Penelitian ini bertujuan untuk mengungkapkan keefektifan pembelajaran berbantuan internet di sekolah menengah kejuruan (SMK) Se-Kota Yogyakarta. Sekolah-sekolah tersebut dipilih yang memiliki kompetensi keahlian Teknik Komputer dan Jaringan (TKJ) dan sudah melaksanakan pembelajaran berbantuan internet sebagai persiapan untuk menyambut Asian Community 2015 pada kerjasama Promoting Information and Comunication Technology (ICT), sehingga perlu diketahui sejauh mana keefektifannya. Penelitian ini merupakan penelitian expost facto. Variabel penelitiannya adalah penguasaan strategi pembelajaran guru, sikap siswa, kualifikasi guru, dan kelengkapan sarana dan prasarana laboratorium komputer. Populasi penelitian ini adalah siswa kelas 2 dan seluruh guru yang mengajar kelas 2 kompetensi keahlian teknik komputer dan jaringan. Instrumen yang digunakan dalam penelitian ini berupa angket untuk guru dan siswa, dan lembar observasi untuk kelengkapan sarana dan prasarana laboratorium komputer. Hasil analisis deskriptif mengungkapkan bahwa penguasaan strategi pembelajaran guru berada pada kategori baik (rerata 150,52) dengan tingkat kecendrungan sebesar 53,29\% belum memenuhi standar yang telah ditetapkan pada kategori pembelajaran yang efektif, dan sikap siswa berada pada kategori baik (rerata 62,95) dengan tingkat kecendrungan sebesar 54,31\%. Secara keseluruhan pembelajaran berbantuan internet di SMK Se-Kota Yogyakarta sudah efektif, meskipun penguasaan strategi pembelajaran guru perlu ditingkatkan dengan mengikutsertakan mereka pada pelatihan-pelatihan yang berhubungan dengan pembelajaran berbantuan internet.
\end{abstract}

Kata kunci: keefektifan pembelajaran, sekolah menengah kejuruan, teknik komputer dan jaringan

\section{THE EFFECTIVENESS OF THE INTERNET-ASSISTED TEACHING OF THE EXPERTISE COMPETENCY OF COMPUTER AND NETWORK ENGINEERING IN VOCATIONAL HIGH SCHOOLS IN YOGYAKARTA CITY}

\begin{abstract}
This study aims to investigate the effectiveness of the internet-assisted teaching in vocational high schools (VHSs) in Yogyakarta City. The selected schools are those running the expertise competency of Computer and Network Engineering (CNE) and implementing the internet-assisted teaching as a preparation to welcome Asian Community 2015 in the cooperation in Promoting Information and Communication Technology so that the effectiveness needs investigating. This was an ex post facto study. The research variables were teachers' mastery of teaching strategies, students' attitudes, teachers' qualifications, and adequacy of infrastructure facilities in the computer laboratory. The research population comprised Grade 2 students and all teachers of Grade 2 teaching the expertise competency of CNE. The research instruments included questionnaires for teachers and students and an observation sheet for the adequacy of infrastructure facilities in the computer laboratory. The results of the descriptive analysis reveal that teachers' mastery of teaching strategies is in the
\end{abstract}


good category (with a mean of 150,52) at a tendency level of 53,29\%, which has not satisfied the standard set for the effective teaching category; students'attitude is in the moderate category (with a mean of 62,95) at a tendency level of 54,31\%. On the whole, the internet-assisted teaching in VHSS in Yogyakarta City is already effective, although for the mastery of teaching strategies teachers need to improve themselves by attending trainings related to the internet-assisted teaching.

Keywords: learning effectiveness, vocational high school, computer and network engineering

\section{PENDAHULUAN}

Perkembangan teknologi informasi terutama di Indonesia semakin pesat. Adanya Teknologi Informasi dan Komunikasi (TIK) dapat memudahkan kita untuk belajar dan mendapatkan informasi. Salah satu yang dirasa paling berperan dalam dunia TIK di Indonesia saat ini adalah perkembangan internet. Berdasarkan Deklarasi ASEAN Concord II (Bali Concord II) yang dihasilkan saat KTT ASEAN ke-9 di Bali, Oktober 2003, di tegaskan akan dibentuknya suatu komunitas Negara-negara ASEAN yang disebut dengan ASEAN COMMUNITY, dimana Deklarasi tersebut menghasilkan 3 pilar kerjasama komunitas antara lain Komunitas Keamanan ASEAN (ASEAN Security Community/ASC), Komunitas Ekonomi ASEAN (ASEAN Economic Community/ $A E C$ ), dan Komunitas Sosial Budaya ASEAN (ASEAN Socio Cultural Community/ASCC).

Dalam hubungannya dengan pendidikan, Komunitas ASEAN telah memiliki program untuk meningkatkan pendidikan salah satunya adalah yang berbasis TIK, program tersebut masuk dalam kerjasama Komunitas Sosial Budaya dalam Promoting Information and Comunication Technology (ICT). Beberapa strateginya antara lain adalah: (1) melaksanakan program peningkatan kapasitas untuk meningkatkan pengetahuan TIK di ASEAN, termasuk perempuan, anak, orang tua dan orang cacat; (2) mempromosikan penggunaan TIK khususnya internet; (3) mendorong pengenalan TIK di semua tingkat pendidikan; (4) merencanakan penggunaan TIK yang di mulai di sekolah dasar; (5) meningkatkan penggunaan TIK dengan mempromosikan e-learning; dan (6) mengembangkan tenaga kerja yang memiliki kemampuan dan keahlian tingkat tinggi dalam bidang ICT (Association of southeast Asian Nations: 2009).
Bertitik tolak dari dicanangkannya ASEAN Community tahun 2015 nanti, maka setiap negara anggota komunitas tersebut akan terjadi pertukaran aspek sosial maupun budaya diantaranya dalam bidang pendidikan adalah pertukaran pelajar, guru/dosen, informasi, teknologi, dan lain-lain. Hal ini mendorong setiap negara untuk mempersiapkan, merencanakan program tersebut dari sekarang. Oleh karena itu sudah sepatutnya setiap sekolah ataupun universitas mulai memperhatikan hal ini khusunya dalam bidang TIK, dalam hal ini adalah Informasi melalui media internet, yang bisa menjadi salah satu kunci untuk membuat dunia pendidikan di Indonesia mempunyai standar yang sama dengan negara lain. Dengan menggunakan media internet, pemerintah, institusi pendidikan dan sekolah-sekolah dapat menerapkan pola belajar yang cukup efektif untuk diterapkan bagi masyarakat yang memiliki kendala dengan jarak dan waktu untuk mendapatkan informasi terutama informasi dalam dunia pendidikan.

Saat ini sekolah dalam pelaksanaan proses pembelajaran yang memanfaatkan TIK kadang menghadapi berbagai kendala yang tidak sederhana. Masalah utama yang seringkali dihadapi oleh pihak sekolah dan guru adalah keterbatasan sarana prasarana, sumber belajar, dan sumber daya manusia (SDM) yang menguasai internet juga menjadi masalah besar bagi dunia pendidikan. Meskipun laboratorium dimiliki oleh sekolah, tetapi baik guru, kepala sekolah dan tenaga pendidikan lainnya belum menguasai dengan baik soal internet. Oleh sebab itu, seiring dengan pengadaan komputer dan jaringan internet disekolah-sekolah, maka perlu disiapkan SDM seperti guru dan teknisi yang menguasai internet. TIK khususnya internet diindonesia harus diakui relatif jauh tertinggal dibandingkan Negara-negara berkembang lainnya apalagi dengan negara 
maju terutama dibidang pendidikan. Selain itu akses internet di sekolah masih rendah terutama didaerah pedesaan dan daerah terpencil sampai saat ini masih rendah bahkan hampir tidak ada (Lilik Gani: 2009).

Direktorat Pembinaan Sekolah Menengah Kejuruan (Dir.PSMK) terus bekerja keras sampai sekarang untuk mensosialisasikan pemanfaatan internet bagi sekolah SMK dengan melalui pendidikan dan pelatihan, workshop bagi guru-guru dan penyediaan infrastruktur, sehingga penggunaan internet diharapkan banyak digunakan dibidang pendidikan khususnya di SMK. Terbukti saat ini lebih kurang 18.000 sekolah atau lembaga pendidikan mulai SD hingga perguruan tinggi di Indonesia telah terkoneksi akses internet yang digelar PT. Telekomunikasi Indonesia Tbk (Telkom) melalui program "Indonesia Digital School" atau Indischool (Dikdas Kemdikbud: 2013). Di Yogyakarta yang dikenal sebagai kota pelajar merupakan salah satu kota diindonesia yang perkembangan internetnya sangat pesat, hal ini dapat dilihat dengan banyaknya warung internet, selain itu saat ini pengunaan modem yang sangat semarak oleh setiap kalangan. Saat ini di Yogyakarta sudah sekitar 101 sekolah telah tersambung dengan Indonesia Digital School (Indischool) (Republika: 2013), oleh karenanya bukan hal yang mustahil untuk kedepannya pemanfaatan internet dalam pembelajaran disetiap sekolah akan dapat terlaksana sehingga baik para siswa dan guru dapat cepat memperoleh informasi yang berkaitan dengan pembelajaran, dan proses belajar mengajar pun tidak harus melalui tatap muka dikelas seperti misalnya Program Teknik Komputer dan Jaringan (TKJ). Dimana Program tersebut sebagian telah menggunakan system pembelajaran online/berbasis internet yang disebut dengan e-learning.

Beberapa definisi umum dari e-learning, diberikan oleh Gilbert \& Jones (2001), yaitu: pengiriman materi pembelajaran melalui suatu media elektronik seperti Internet, intranet/ extranet, satellite broadcast, audio/video tape, interactive TV, CD-ROM, dan computer-based training (CBT). Definisi yang hampir sama diusulkan juga oleh the Australian National Training Authority (2003) yakni meliputi aplikasi dan proses yang menggunakan berbagai media elektronik seperti internet, audio/video tape, interactive $T V$ and $C D-R O M$ guna mengirimkan materi pembelajaran secara lebih fleksibel. The ILRT of Bristol University (2005) mendefinisikan e-learning sebagai penggunaan teknologi elektronik untuk mengirim, mendukung, dan meningkatkan pengajaran, pembelajaran dan penilaian. Udan and Weggen (2000) menyebutkan bahwa e-learning adalah bagian dari pembelajaran jarak jauh sedangkan pembelajaran online adalah bagian dari e-learning. Di samping itu, istilah e-learning meliputi berbagai aplikasi dan proses seperti computer-based learning, web-based learning, virtual classroom, dll; sementara itu pembelajaran on-line adalah bagian dari pembelajaran berbasis teknologi yang memanfaatkan sumber daya Internet, intranet, dan extranet. Lebih khusus lagi Rosenberg (2001) mendefinisikan e-learning sebagai pemanfaatan teknologi Internet untuk mendistribusikan materi pembelajaran, sehingga siswa dapat mengakses dari mana saja (Surjono, 2008, p 3)

Dalam pembelajaran berbasis internet, strategi pembelajaran dan model pembelajaran merupakan hal yang perlu diperhatikan dalam meningkatkan kualitas pembelajaran. Selain dari strategi pembelajaran, seorang guru harus memiliki kualifikasi sesuai dengan bidangnya, agar proses pembelajaran dapat berjalan dengan baik. Strategi pembelajaran oleh guru merupakan salah satu faktor yang berpengaruh terhadap pencapaian kompetensi lulusan. Strategi pembelajaran telah mengalami perkembangan yang cukup pesat seiring dengan perkembangan TIK. Salah satu diantaranya adalah e-learning. E-learning telah menjadi kebutuhan bagi sekolah terutama SMK. Di Yogyakarta telah banyak SMK yang telah memanfaatkan e-learning sebagai media pembelajaran berbasis internet, karena baik guru, siswa maupun institusi pendidikan telah memanfaatkan teknologi komputer dalam proses kegiatan belajar mengajar.

Dalam kegiatan belajar mengajar sikap siswa merupakan bagian penting untuk diperhatikan karena aktifitas belajar siswa selanjutnya banyak ditentukan oleh sikap siswa ketika akan memulai kegiatan belajar. 
Aunurrahman (2008) mengatakan ketika akan memulai kegiatan belajar siswa memiliki sikap menerima atau ada kesediaan emosional untuk belajar, maka ia akan cenderung untuk berusaha terlibat dalam kegiatan belajar dengan baik, namun bilamana yang lebih dominan adalah sikap menolak sebelum belajar atau ketika akan memulai pembelajaran, maka siswa cenderung kurang memperhatikan/mengikuti kegiatan belajar. Sikap terhadap belajar juga nampak dari kesungguhan mengikuti pelajaran, atau sebaliknya bersikap acuh terhadap aktivitas belajar. Oleh karena itu, guru harus mampu mengaktualisasikan tugas-tugas dengan baik, mampu memfasilitasi kegiatan belajar siswa, mampu memotivasi, membimbing dan memberi kesempatan secara luas untuk memperoleh pengalaman.

Pemanfaatan pembelajaran berbasis internet (e-learning) diharapkan dapat memotivasi peningkatan kualitas pembelajaran dan materi ajar, kualitas aktivitas dan kemandirian siswa, serta komunikasi antara guru dan siswa maupun antara siswa. e-learning juga dapat digunakan untuk mengatasi keterbatasan ruang kelas serta hambatan jarak dan waktu, didalam pelaksanaan kegiatan belajar mengajar. Oleh karena itu dalam penggunaan suatu media pembelajaran sekolah perlu mengetahui keefektifan dari media tersebut, agar bisa diketahui seberapa besar keefektifan media tersebut bagi pembelajaran disekolah yang telah memanfaatkan media tersebut. Sehingga nantinya dapat kita lihat kesiapan suatu sekolah dalam rangka menuju ASEAN Community.

\section{Strategi Pembelajaran}

J.R. David dalam Sanjaya (2006, p.126) mengatakan didalam dunia pendidikan, strategi diartikan sebagai "a plan Method, or series of activities designed to achieves a particular educational goal". Dengan demikian strategi pembelajaran diartikan sebagai perencanaan yang berisi tentang rangkaian kegiatan yang didesain untuk mencapai tujuan pendidikan tertentu.

Schmeck (1988, p.5) mengatakan bahwa "A learning strategy is a sequence of procedures for accomplishing learning, and the specific procedures within this sequence are called learning tactics". Strategi pembelajaran adalah sebuah urutan prosedur untuk mencapai tujuan pembelajaran dan prosedur tertentu, prosedur ini disebut taktik pembelajaran.

Schumaker \& Deshler dalam Eric dan Osep (2008, p.4) mendefinisikan bahwa:

A learning strategy is an individual's approach to complete a task. More specifically, a learning strategy is an individual's way of organizing and using particular set of skills in order to learn content or accomplish other tasks more effectively and efficiently in school as well as in nonacademic setting. Therefore, teachers who teach learning strategies teach students how to learn, rather than teaching them specific curriculum content or specific skills."

Strategi pembelajaran adalah sebuah pendekatan individu dalam menyelesaikan tugas. Lebih khususnya, strategi pembelajaran adalah cara seseorang mengorganisir dan menggunakan satu set keterampilan tertentu untuk mempelajari isi atau menyelesaikan tugas-tugas lain dengan lebih efektif dan efisien di sekolah sama baiknya dalam seting nonakademik. Oleh karena itu, para guru yang mengajar strategi belajar, lebih mengajarkan pada siswa bagaimana cara untuk belajar, daripada mengajarkan pada mereka tentang isi kurikulum yang spesifik atau keterampilan khusus.

Strategi pembelajaran merupakan suatu rencana tindakan yang termasuk penggunaan metode dan pemanfaatan berbagai sumber daya atau kekuatan dalam pembelajaran. Sehingga dalam melaksanakan tugas secara profesional, seorang guru memerlukan wawasan yang mantap tentang kemungkinankemungkinan strategi pembelajaran sesuai dengan tujuan-tujuan belajar, baik dalam arti efek instruksional maupun efek pengiring, yang ingin dicapai berdasarkan rumusan tujuan pendidikan yang utuh, di samping penguasaan teknis di dalam mendesain sistem lingkungan belajar-mengajar dan mengimplementasikan secara efektif apa yang telah direncanakan di dalam desain instruksional. Dalam hal ini penggunaan media berbantuan internet seperti 
e-learning diharapkan menjadi satu kesatuan dalam proses pembelajaran disekolah sehingga akan terbentuk proses komunikasi antara komponen-komponen pendidikan disekolah.

\section{Sikap Siswa}

Menurut Lange seperti yang dikutip oleh Azwar (1995), sikap juga mencakup respon fisik. Selanjutnya dikatakan oleh Berkowitz dalam Azwar (1995) bahwa sikap seseorang terhadap objek adalah perasaan mendukung atau memihak maupun perasaan tidak mendukung atau tidak memihak.

Thurstone dalam Gable (1993) menyebutkan bahwa sikap adalah: "The intensity of positive or negative affect for or against a psychological object. A psychological object is any symbol, person, phrase, slogan, or idea toward which people can differ as regards positive or negative affect". Bahwa sikap sering kali digambarkan sebagai derajat efek positif atau efek negatif terhadap suatu objek psikologis, objek psikologis tersebut adalah dalam bentuk simbol, orang, frase, slogan, atau ide dan pengaruhnya untuk setiap orang bisa berbeda baik secara positif atau negatif.

Allport dalam Oskamp (2005) menyatakan "an attitude is a mental or neural state of readness, organized through experience, exerting a directive or dinamyc influence upon the individual response to all object and situation with which it is realated". Sikap adalah mental atau penyesuaian system syaraf yang berdasarkan pengalaman atau sesuatu yang berpengaruh terhadap individual seseorang terhadap objek dan situasi yang saling berhubungan. Aiken dalam Gable (1993) mengatakan bahwa:

Attitude may be conceptualized as learned predispositions to respond positively or negatively to certain object, situations, concepts, or persons. As such, they posses cognitive (belief or knowledge), affective (emotional, motivational), and performance (behavior or action tendencies) components.

Sikap dapat diartikan sebagai kecenderungan dalam belajar untuk merespon secara positif atau negatif terhadap objek, situasi, konsep, atau orang-orang tertentu. sikap, memiliki komponen kognitif (kepercayaan atau pengetahuan), afektif (emosional, motivasi), dan penampilan (perilaku atau kecenderungan tindakan).

Sikap adalah kondisi mental relatifmenetap untuk merespon suatu objek atau perangsang tertentu yang mempunyai arti, baik bersifat positif, netral, atau negatif, mengangkat aspekaspek kognisi, afeksi, dan kecenderungan untuk bertindak. Sikap siswa terhadap pembelajaran berbantuan internet berkaitan dengan unsur kesadaran, penerimaan, motivasi dan respon siswa terhadap pembelajaran tersebut karena internet merupakan sebuah media yang sangat berpengaruh pada prilaku siswa dalam proses pembelajaran.

\section{Kualifikasi Guru}

Didalam Kamus Besar Bahasa Indonesia (2013), yang dimaksud dengan kualifikasi adalah (1) pedidikan khusus untuk memperoleh suatu keahlian; (2) keahlian yang diperlukan untuk melakukan sesuatu (menduduki jabatan, dsb). Elizabeth Holmes (2010) dalam British qualification 2010 menjelaskan bahwa kualifikasi adalah:

\section{A qualification is normally a certificated endorsement, from a recognized awarding body, that a level or quality of accomplish- ment has been achieved by an individual. Qualifications are usually conferred on successful completion of an examination, although not all examinations necessarily offer qualifications. An examination may offer an award that is a part-qualification.}

Kualifikasi merupakan suatu bentuk dukungan yang bersertifikat, yang diakui oleh suatu lembaga sebagai penghargaan prestasi yang telah dicapai oleh seseorang. Kualifikasi biasanya diberikan setelah seseorang berhasil menyelesaikan suatu ujian, walaupun tidak semua dalam bentuk ujian. Dengan diberikannya suatu penghargaan ini merupakan bagian kualifikasi itu sendiri.

Miarso (2008) mengatakan bahwa guru yang berkualifikasi adalah guru yang memenuhi standar pendidik, menguasai materi/isi pelajaran sesuai dengan standar isi, dan menghayati dan melaksanakan proses pembelajaran sesuai dengan standar proses pembelajaran. Miarso mengartikan kualifikasi sebagai kemampuan 
atau kompetensi yang harus dimiliki seorang guru dalam melaksanakan tugasnya.

Menurut peraturan pemerintah Nomor 19 tahun 2005, kualifikasi akademik adalah tingkat pendidikan minimal yang harus dipenuhi oleh seorang pendidik yang dibuktikan dengan ijazah dan atau sertifikasi keahlian yang relevan sesuai ketentuan perundang-undangan yang berlaku.

\section{Sarana dan Prasarana}

Menurut Mulyasa (2012) sarana pendidikan adalah peralatan dan perlengkapan yang secara langsung dipergunakan dan menunjang proses pendidikan, khususnya proses belajar mengajar seperti gedung, ruang kelas, mejakursi, alat-alat dan media pengajaran. Adapun yang dimaksud prasarana adalah fasilitas yang secara tidak langsung menunjang jalannya proses pendidikan atau pengajaran seperti halaman, kebun, taman sekolah dan jalan menuju sekolah.

Menurut Ibrahim Bafadal dalam Minarti (2012), sarana pendidikan adalah "semua perangkatan peralatan, bahan dan perabot yang secara langsung digunakan dalam proses pendidikan di sekolah".

Dalam Peraturan Menteri pendidikan Nasional Nomor 40 tahun 2008, dijelaskan bahwa Sarana adalah perlengkapan pembelajaran yang dapat dipindah-pindah. Sedangkan Prasarana adalah fasilitas dasar untuk menjalankan fungsi SMK/MAK.

Menurut Nawawi dalam Minarti (2012), dalam hubungannya dengan proses belajar mengajar, ada dua jenis sarana pendidikan. Pertama, sarana pendidikan yang secara langsung digunakan dalam proses belajar mengajar. Sebagai contohnya adalah kapur tulis, atlas dan sarana pendidikan lainnya yang digunakan guru dalam mengajar. Kedua, sarana pendidikan yang secara tidak langsung berhubungan dengan proses belajar mengajar, seperti lemari arsip di kantor sekolah merupakan sarana pendidikan yang secara tidak langsung digunakan oleh guru dalam proses belajar mengajar.

Sarana dan prasarana adalah alat penunjang keberhasilan suatu proses upaya yang dilakukan di dalam pelayanan publik yang san- gat penting meliputi peralatan, perlengkapan, fasilitas yang berfungsi untuk mencapai tujuan yang hendak dicapai. Sarana dan prasarana pada sekolah harus memiliki standar yang berbasis TIK, agar pembelajaran berbantuan internet dapat terlaksana dengan baik.

\section{Keefektifan}

Menurut Kamus Besar Bahasa Indonesia (KBBI) definisi efektivitas adalah sesuatu yang memiliki pengaruh atau akibat yang ditimbulkan, manjur, membawa hasil dan merupakan keberhasilan dari suatu usaha atau tindakan, dalam hal ini efektivitas dapat dilihat dari tercapai tidaknya tujuan instruksional khusus yang telah dicanangkan. Metode pembelajaran dikatakan efektif jika tujuan instruksional khusus yang dicanangkan lebih banyak tercapai.

Slavin (2006) menyatakan bahwa terdapat empat indikator dalam menentukan keefektifan pembelajaran, yaitu:

\section{Kualitas Pembelajaran}

Kualitas pembelajaran dapat terlihat dari ketercapaian tujuan instruksional pembelajaran yang terdapat pada indikator pembelajaran dan kemampuan anak setelah penerapan pembelajaran.

\section{Kesesuaian Tingkat Pembelajaran}

Hal ini terlihat pada indikator ketercapaian yang terdapat pada silabus atau program tahuan atau program semester yang telah direncanakan oleh guru.

\section{Insentif}

Cara guru memberikan motivasi yang dapat terlihat dari respon dan minat siswa saat berlangsungnya pembelajaran.

\section{Waktu}

Keefisienan waktu dan pengaturan waktu yang telah dilakukan oleh guru dalam proses pembelajaran

Keefektifan merupakan suatu tingkat keberhasilan terhadap suatu pembelajaran. Keefektifan dapat diukur berdasarkan skor yang capai siswa, baik melalui skor tes, penilaian hasil kerja, dan pengamatan tingkah laku pada siswa. 
Tujuan penelitian ini adalah untuk: (1) mengetahui penguasaan strategi pembelajaran guru di SMK yang telah memanfaatkan internet; (2) mengetahui sikap siswa pada pembelajaran berbantuan internet di SMK yang telah memanfaatkan Internet; (3) mengetahui kualifikasi guru di SMK yang telah memanfaatkan internet; (4) mengetahui pemenuhan standar minimal laboratorium komputer pendukung pembelajaran berbantuan internet; (5) mengetahui pengaruh penguasaan strategi pembelajaran guru dan sikap siswa terhadap efektivitas pembelajaran berbantuan internet di SMK yang telah memanfaatkan internet.

\section{METODE}

\section{Jenis Penelitian}

Penelitian ini menggunakan pendekatan kuantitatif dan merupakan penelitian korelasional yang bertujuan untuk mencari ada tidaknya hubungan antara variabel bebas dengan variabel terikat. Pada penelitian ini tidak ada pengendalian atau perlakuan terhadap variabel bebas secara langsung karena peristiwa telah terjadi, sehingga penelitian ini termasuk penelitian ex-post facto (Sukardi: 2013, p 165)

\section{Tempat dan Waktu Penelitian}

Penelitian ini dilaksanakan di 7 (tujuh) Sekolah Menengah Kejuruan (SMK) pada kompetensi Teknik Komputer dan Jaringan (TKJ) yang telah melaksanakan pembelajaran dengan memanfaatkan internet yang ada di Yogyakarta. Waktu penelitian dilaksanakan pada Semester Genap tahun pelajaran 2012/2013.

\section{Populasi dan Sampel Penelitian}

Populasi penelitian adalah siswa kelas XI (sebelas) SMK kompetensi Teknik Komputer dan Jaringan di Wilayah Kota Yogyakarta, yakni SMK Muhammadiyah 1 Yogyakarta, SMK Muhammadiyah 2 Yogyakarta, SMK Muhammadiyah 3 Yogyakarta, SMK N 2 Yogyakarta, SMK N 3 Yogyakarta, SMK Tamansiswa Yogyakarta, dan SMK PIRI 1 Yogyakarta sejumlah 277 orang. Dipilihnya siswa kelas XI dengan pertimbangan bahwa siswa kelas X (sepuluh) masih dalam tahap penyesuaian atau pengenalan pembelajaran. Adapun siswa kelas XII (dua belas) sedang disibukkan dengan persiapan ujian nasional. Sedangkan jumlah gurunya adalah 35 orang guru di SMK Se-Kota Yogyakarta kompetensi TKJ. Sampel penelitian diambil dengan secara purposive sampling dan dengan menggunakan tabel Isaac dan Michael dengan taraf signifikansi 1\%, sehingga sampelnya berjumlah 197 siswa.

\section{Teknik Pengumpulan Data}

Pengumpulan data dilakukan dengan metode observasi, angket dan dokumentasi. Observasi dan dokumentasi digunakan untuk memperolah data kelengkapan sarana dan prasarana laboratorium komputer. Angket digunakan untuk mengungkap informasi mengenai strategi pembelajaran yang dilakukan oleh guru beserta kualifikasinya, sikap siswa terhadap pembelajaran, dan sarana prasarana yang ada di SMK di Kota Yogyakarta. Angket disusun menurut model skala likert. Angket penelitian sebelum digunakan divalidasi ahli dan diujicobakan pada 40 siswa untuk menguji validitas dan realiabilitas instrumen.

\section{Teknik Analisis Data}

Teknik analisis data dengan menggunakan analisis deskriptif dan infrensial (korelasi parsial dan regresi ganda) menggunakan program SPSS for windows 17, yang sebelumnya data telah melalui uji prasyarat analisis antara lain: uji normalitas, linieritas, dan multikolinieritas.

\section{HASIL PENELITIAN DAN PEMBAHASAN}

\section{Deskripsi Data}

\section{Hasil Data Penguasaan Strategi Pembelaja- ran Guru}

Berdasarkan data strategi pembelajaran guru yang terkumpul secara keseluruhan, diperoleh skor terendah 114 dan skor tertinggi 196 pada rentang skor 40 sampai dengan 200; dengan rerata ideal (Mi) sebesar 120; dan simpangan baku ideal (SDi) sebesar 26,6; hasil analisis data diperoleh harga rerata $(\mathrm{M})=$ 150,52 , standar deviasi $(\mathrm{SD})=258,42$. Hasil perolehan skor dari responden berdasarkan kategori sebagai berikut (Tabel 1). 
Tabel 1. Distribusi frekuensi kecendrungan penguasaan strategi Pembelajaran guru

\begin{tabular}{lccc}
\hline Rentang Skor & Kategori & Frekuensi & Persentase \\
\hline$>159,9$ & Sangat Baik & 62 & 31,47 \\
$133,3-159,89$ & Baik & 105 & 53,29 \\
$106,7-133,29$ & Cukup & 30 & 15,22 \\
$80,1-106,69$ & Kurang & - & - \\
$\leq 80$ & Sangat Kurang & - & - \\
\hline Jumlah & & $\mathbf{1 9 7}$ & $\mathbf{1 0 0}$ \\
\hline
\end{tabular}

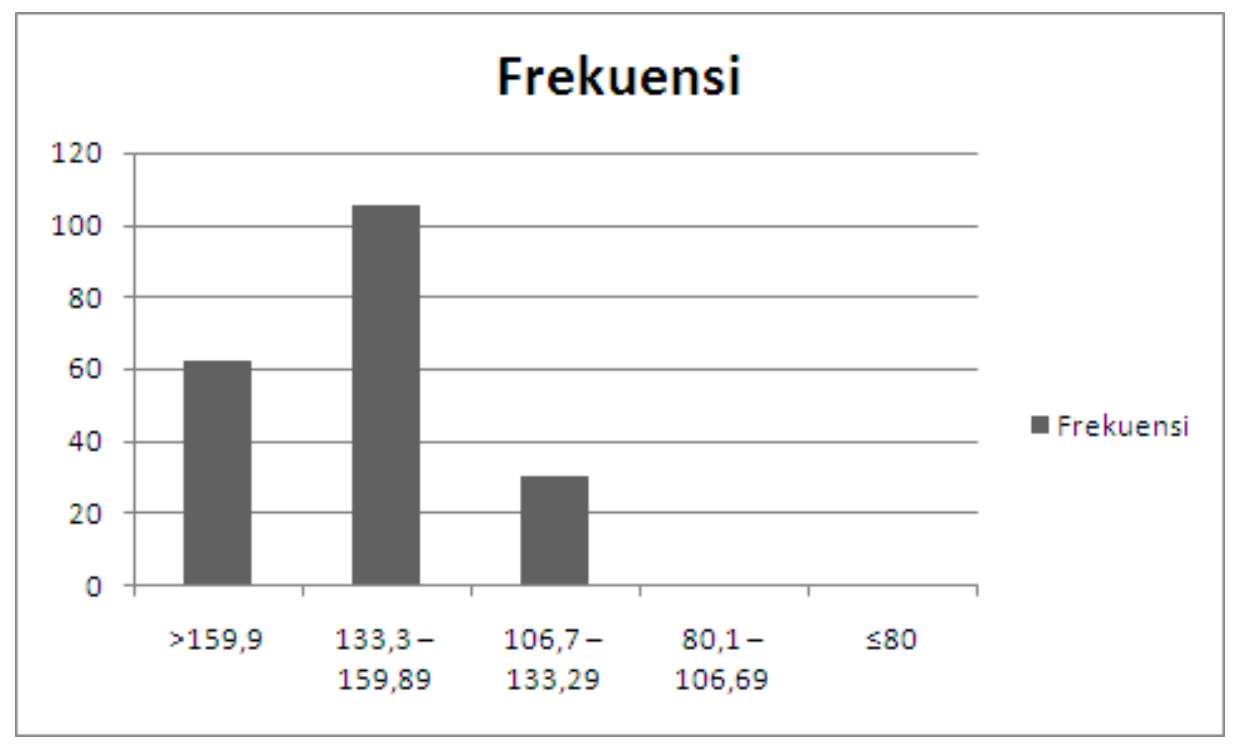

Gambar 1. Diagram penguasaan strategi pembelajaran Guru

Hasil analisis persepsi terhadap penguasaan strategi pembelajaran guru memanfaatkan internet sebagai media pembelajaran diperoleh terdapat pada kategori sangat baik sebanyak 62 siswa dengan persentase $31,47 \% ; 105$ siswa berada pada kategori baik dengan persentase $53,29 \%$; dan 30 siswa berada pada kategori cukup dengan persentase $15,22 \%$. Dari hasil analisis diatas dapat dilihat bahwa persepsi siswa terhadap penguasaan strategi pembelajaran yang dimiliki beberapa guru sudah baik, walaupun masih banyak guru yang belum memiliki penguasaan strategi dalam pembelajaran, hal ini disebabkan karena adanya beberapa faktor yang mempengaruhi misalnya dalam segi latar belakang pendidikan guru, pengetahuan dibidang teknologi informasi dan komunikasi kurang, jarang mengikuti pelatihanpelatihan yang berhubungan dengan internet, sehingga penguasaan strategi pembelajaran yang dimiliki guru tersebut berbeda-beda.

\section{Hasil data Sikap Siswa}

Berdasarkan data yang terkumpul dari data total sikap siswa, diperoleh skor terendah 46 dan skor tertinggi 80 pada rentang skor 16 sampai dengan 90; dengan rerata ideal (Mi) sebesar 53; dan simpangan baku ideal (SDi) sebesar 12,3; hasil analisis data diperoleh harga rerata $(M)=62,95$, standar deviasi $(\mathrm{SD})$ $=57,70$. Hasil perolehan skor dari responden berdasarkan kategori sebagai berikut (Tabel 2).

Hasil analisis terhadap sikap siswa memanfaatkan internet sebagai media pembelajaran berdasarkan sikap siswa terdiri dari kesadaran dan penerimaan diperoleh hasil 37 siswa berada pada kategori sangat baik dengan persentase 18,78\%; 107 siswa berada pada kategori baik dengan persentase $54,71 \%$; dan 53 siswa berada pada kategori cukup dengan persentase $26,90 \%$. Dari hasil analisis diatas dapat kita lihat bahwa sikap siswa terhadap pembelajaran berbantuan internet sudah baik, 
Tabel 2. Distribusi frekuensi kecendrungan sikap siswa

\begin{tabular}{lccc}
\hline Rentang Skor & Kategori & Frekuensi & Persentase \\
\hline$>71,45$ & Sangat Baik & 37 & 18,78 \\
$59,15-71,44$ & Baik & 107 & 54,31 \\
$46,85-59,14$ & Cukup & 53 & 26,9 \\
$34,55-46,84$ & Kurang & - & - \\
$\leq 34,54$ & Sangat Kurang & - & - \\
\hline Jumlah & & $\mathbf{1 9 7}$ & $\mathbf{1 0 0}$ \\
\hline
\end{tabular}

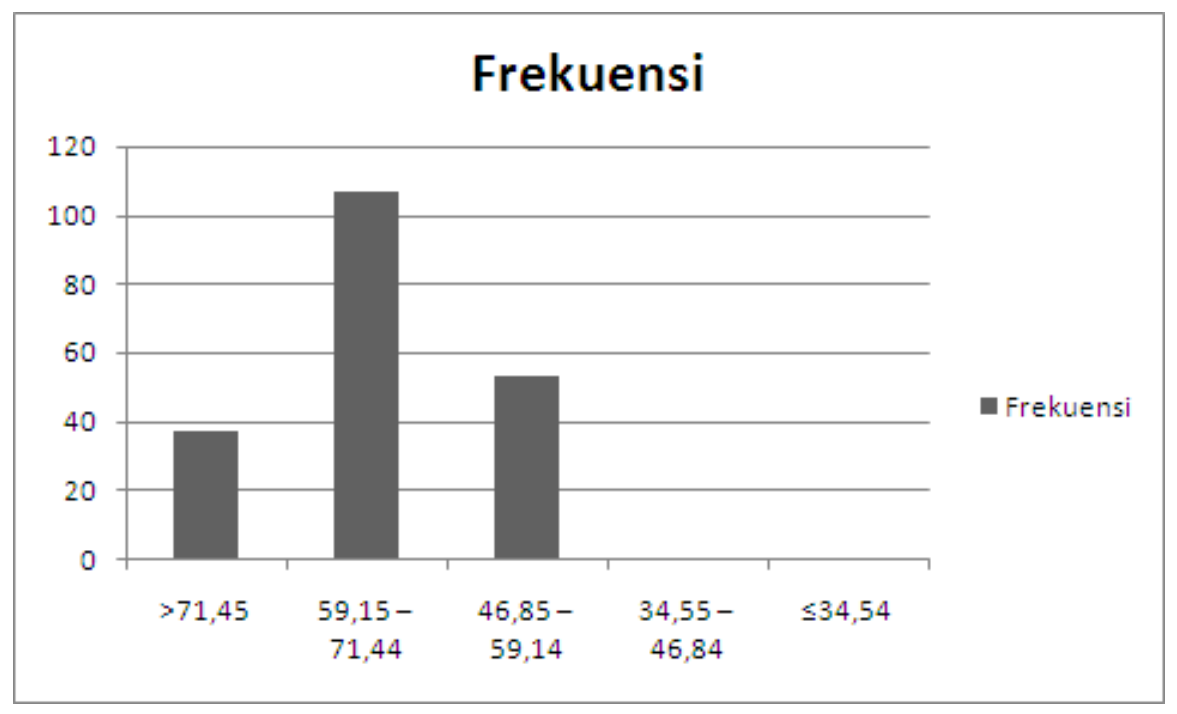

Gambar 2. Diagram sikap siswa terhadap pembelajaran internet

walaupun berbeda-beda sebagian besar siswa memiliki antusias yang tinggi akan keberadaan internet sebagai media pembelajaran tersebut dari segi kesadaran dan penerimaan terhadap pembelajaran memanfaatkan internet sebagai media pembelajaran, tetapi masih banyak juga siswa yang kurang motivasi dalam pembelajaran tersebut.

\section{Hasil Data Kualifikasi Guru}

Berdasarkan data kualifikasi guru yang terkumpul secara keseluruhan, diperoleh skor terendah 10 dan skor tertinggi 38 pada rentang skor 8 sampai dengan 40; dengan rerata ideal (Mi) sebesar 24; dan simpangan baku ideal (SDi) sebesar 5,33; hasil analisis data diperoleh harga rerata $(\mathrm{M})=23,4$, standar deviasi $(\mathrm{SD})=$ 40,4. Hasil perolehan skor dari responden berdasarkan kategori sebagai berikut (Tabel 3).
Hasil analisis deskriptif standar kualifikasi guru bidang TIK yaitu 5 orang guru berada pada kategori sangat baik dengan persentase $14,28 \%$; 7 orang guru berada pada kategori baik dengan persentase $20 \%$; 8 orang guru berada pada kategori cukup dengan persentase $22,8 \% ; 10$ orang guru berada pada kategori kurang dengan persentase $28,5 \%$; dan 5 orang guru berada pada kategori sangat kurang dengan persentase 14,28\%. Dari hasil analisis diatas dapat kita lihat bahwa sebagian guru sudah memiliki kualifikasi yang baik, walaupun sebagian ada yang belum memiliki kualifikasi yang sesuai, hal ini disebabkan karena beberapa faktor yaitu tidak sesuai dengan latar belakang pendidikan yang diajarkan, kurangnya pengalaman kerja maupun pelatihan-pelatihan yang berhubungn dengan pembelajaran internet. 
Tabel 3. Distribusi frekuensi kecendrungan kualifikasi guru

\begin{tabular}{lccc}
\hline Rentang Skor & Kategori & Frekuensi & Persentase \\
\hline$\geq 31,99$ & Sangat Baik & 5 & 14,28 \\
$26,65-31,98$ & Baik & 7 & 20 \\
$21,35-26,64$ & Cukup & 8 & 22,8 \\
$16,01-21,34$ & Kurang & 10 & 28,5 \\
$\leq 16$ & Sangat Kurang & 5 & 14,28 \\
\hline Jumlah & & $\mathbf{3 5}$ & $\mathbf{1 0 0}$ \\
\hline
\end{tabular}

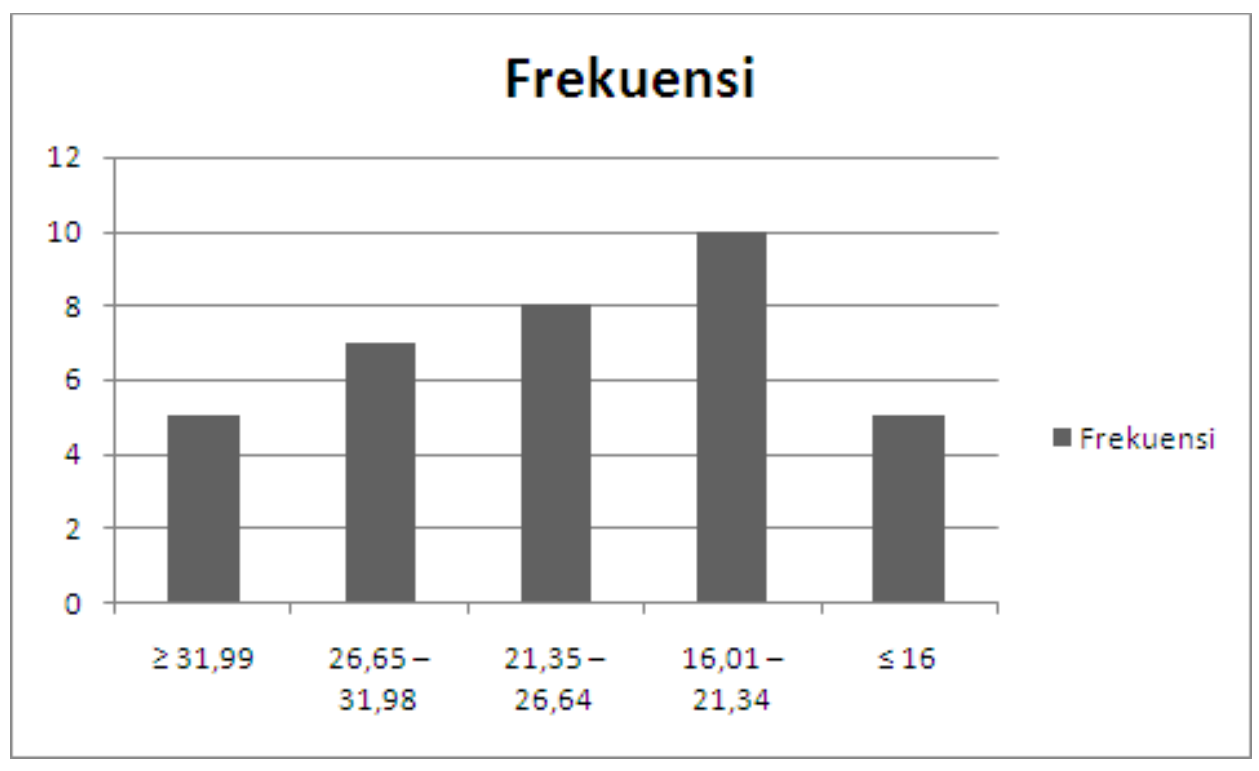

Gambar 3. Diagram kualifikasi guru

\section{Hasil Data Sarana dan Prasarana}

Berdasarkan data sarana dan prasarana laboratorium komputer yang terkumpul secara keseluruhan, diperoleh skor terendah 27 dan skor tertinggi 35 pada rentang skor 7 sampai dengan 35; dengan rerata ideal (Mi) sebesar 21; dan simpangan baku ideal (SDi) sebesar 4,66; hasil analisis data diperoleh harga rerata $(\mathrm{M})=32,42$, standar deviasi $(\mathrm{SD})=6,53$. Hasil perolehan skor dari responden berdasarkan kategori sebagai berikut (Tabel 4).

Hasil observasi sarana dan prasarana laboratorium komputer ternyata secara keseluruhan telah memenuhi standar minimal laboratorium komputer dan sesuai dengan peraturan Menteri Pendidikan Nasional Republik Indonesia Nomor 40 Tahun 2008 Tentang Standar Sa- rana Dan Prasarana. Dimana berdasarkan hasil analisis sarana dan prasarana pada SMK berada pada kategori yang sangat baik dengan persentase $85,71 \%$; dan kategori baik dengan persentase $14,28 \%$.

\section{Hasil Data Keefektifan Pembelajaran Internet}

Berdasarkan data yang terkumpul dari data efektifitas pembelajaran berbantuan internet, diperoleh skor terendah 49 dan skor tertinggi 80 pada rentang skor 16 sampai dengan 90; dengan rerata ideal (Mi) sebesar 53; dan simpangan baku ideal (SDi) sebesar 12,3; hasil analisis data diperoleh harga rerata $(\mathrm{M})$ $=62,38$, standar deviasi $(\mathrm{SD})=48,06$. Hasil perolehan skor dari responden berdasarkan kategori sebagai berikut (Tabel 5). 
Tabel 4. Distribusi frekuensi kecendrungan kualifikasi guru

\begin{tabular}{lccc}
\hline Rentang Skor & Kategori & Frekuensi & Persentase \\
\hline$>27,99$ & Sangat Baik & 6 & 85,71 \\
$23,33-27,98$ & Baik & 1 & 14,28 \\
$18,67-23,32$ & Cukup & - & - \\
$14,1-18,66$ & Kurang & - & - \\
$\leq 14,09$ & Sangat Kurang & - & - \\
\hline Jumlah & & $\mathbf{7}$ & $\mathbf{1 0 0}$ \\
\hline
\end{tabular}

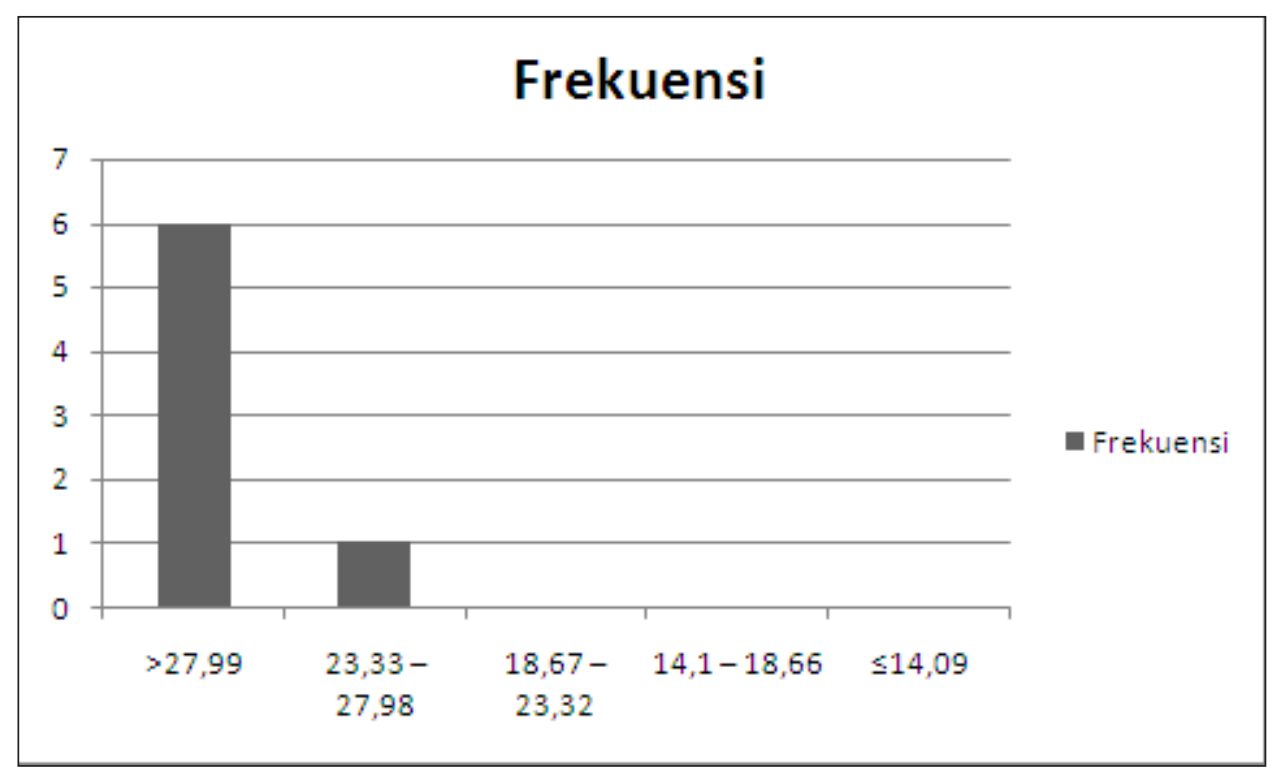

Gambar 4. Diagram sarana dan prasarana laboratorium komputer

Tabel 5. Distribusi frekuensi kecendrungan keefektifan pembelajaran internet

\begin{tabular}{lccc}
\hline Rentang Skor & Kategori & Frekuensi & Persentase \\
\hline$>71,45$ & Sangat Baik & 31 & 15,71 \\
$59,15-71,44$ & Baik & 108 & 54,82 \\
$46,85-59,14$ & Cukup & 58 & 29,44 \\
$34,55-46,84$ & Kurang & - & - \\
$\leq 34,54$ & Sangat Kurang & - & - \\
\hline Jumlah & & $\mathbf{1 9 7}$ & $\mathbf{1 0 0}$ \\
\hline
\end{tabular}

Hasil analisis efektivitas pembelajaran berbantuan internet diperoleh hasil 26 siswa berada pada kategori sangat baik dengan persentase $9,38 \%$; 101 siswa berada pada kategori baik dengan persentase $36,46 \% ; 113$ siswa berada pada kategori cukup dengan persentase 40,79\%; 29 siswa berada pada kategori kurang dengan persentase $10,46 \%$; dan 8 siswa berada pada sangat kurang dengan persentase $2,88 \%$.
Dari hasil analisis diatas dapat kita lihat bahwa pembelajaran berbantuan internet telah berjalan dengan baik, hal ini diartikan bahwa siswa dan guru memiliki antusias yang tinggi serta melaksanakan pembelajaran internet tersebut dengan baik. Walaupun ada sebagian faktor yang mempengaruhi tingkat keefektifan dari pembelajaran tersebut. 


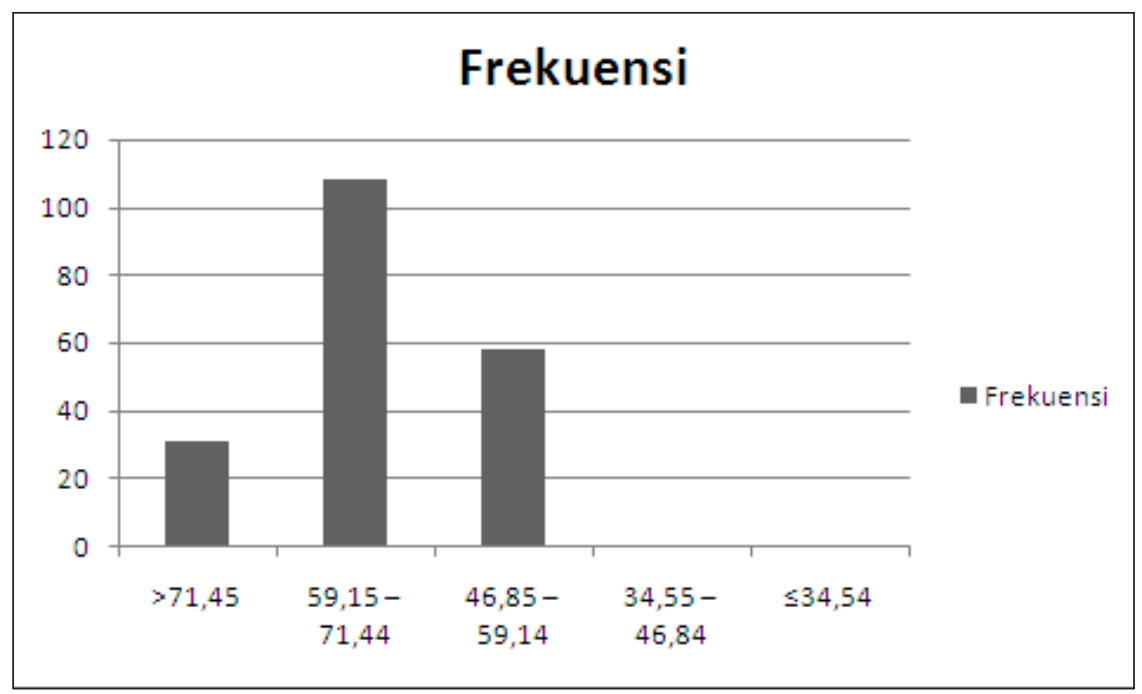

Gambar 5. Diagram keefektifan pembelajaran berbantuan internet

Tabel 6. Korelasi X1, X2 dan Y

\section{Correlations}

\begin{tabular}{rlrrr}
\hline & & $\mathrm{X} 1$ & $\mathrm{X} 2$ & $\mathrm{Y}$ \\
\hline $\mathrm{X} 1$ & Pearson Correlation & 1 & $.826^{* *}$ & $875^{* *}$ \\
& Sig. (2-tailed) & & .000 & .000 \\
& $\mathrm{~N}$ & 197 & 197 & 197 \\
\hline $\mathrm{X} 2$ & Pearson Correlation & $.826^{* *}$ & 1 & $.901^{*}$ \\
& Sig. (2-tailed) & .000 & & .000 \\
& $\mathrm{~N}$ & 197 & 197 & 197 \\
\hline $\mathrm{Y}$ & Pearson Correlation & $875^{* *}$ & $.901^{* *}$ & 1 \\
& Sig. (2-tailed) & .000 & .000 & \\
& $\mathrm{~N}$ & 197 & 197 & 197 \\
\hline
\end{tabular}

** Correlation is significant at the 0.01 level (2-tailed)

\section{Analisis Statistik Inferensial}

Hasil pengujian korelasi melalui bantuan program SPSS 17 for windows maka diperoleh deskripsi/gambaran statistik tentang hubungan variabel strategi pembelajaran (X1), sikap siswa (X2) dan keefektifan (Y) dengan penjelasan disajikan pada tabel 6 .

Dari tabel korelasi diatas dapat dijelaskan sebagai berikut: (1) hubungan antara variabel penguasaan strategi pembelajaran guru (X1) terhadap efektivitas pembelajaran berbantuan internet (Y) diperoleh koefisien korelasi sebesar 0,875 . Dengan signifikansi probabilitas sebesar 0,000 , karena signifikansi probabilitas lebih kecil dari 0,01 atau 0,05 maka Ho ditolak Ha diterima. Dengan demikian dapat disimpul- kan bahwa ada pengaruh dan hubungan positif yang signifikan antara penguasaan strategi pembelajaran guru dalam PBM terhadap efektivitas pembelajaran berbantuan internet; (2) hubungan antara variabel sikap siswa (X2) terhadap efektivitas pembelajaran berbantuan internet (Y) diperoleh koefisien korelasi sebesar 0,901 . Dengan signifikansi probabilitas sebesar 0,000, karena signifikansi probabilitas lebih kecil dari 0,01 atau 0,05 maka Ho ditolak Ha diterima. Dengan demikian dapat disimpulkan bahwa ada pengaruh dan hubungan positif yang signifikan antara sikap siswa terhadap efektivitas pembelajaran berbantuan internet; (3) hubungan antara variabel penguasaan strategi pembelajaran guru (X1) dan 
Tabel 7. Kontribusi X1 terhadap Y

Model Summary

\begin{tabular}{ccccc}
\hline Model & R & R Square & Adjust R Square & Std. Error of the Estimate \\
\hline 1 & $.875^{\mathrm{a}}$ & .766 & .765 & 3.373 \\
\hline
\end{tabular}

a. Predictors: (Constant), X1

Tabel 8. Kontribusi X2 terhadap Y

Model Summary

\begin{tabular}{ccccc}
\hline Model & $\mathrm{R}$ & $\mathrm{R}$ Square & Adjust R Square & Std. Error of the Estimate \\
\hline 1 & $.901^{\mathrm{a}}$ & .812 & .811 & 3.021 \\
\hline
\end{tabular}

a. Predictors: (Constant), X2

Tabel 9. Kontribusi X1dan X2 terhadap Y

Model Summary

\begin{tabular}{cccccc}
\hline Model & $\mathrm{R}$ & $\mathrm{R}$ Square & Adjust R Square & Std. Error of the Estimate & Durbin-Watson \\
\hline 1 & $.931^{\mathrm{a}}$ & .866 & .865 & 2.558 & .293 \\
\hline $\begin{array}{l}\text { a. Predictors: (Constant), X2, X1 } \\
\text { b. Dependent Variable : } \mathrm{Y}\end{array}$
\end{tabular}

variabel sikap siswa (X2) terhadap efektivitas pembelajaran berbantuan internet $(\mathrm{Y})$ diperoleh koefisien korelasi sebesar 0,931. Dengan signifikansi probabilitas sebesar 0,000 , karena signifikansi probabilitas lebih kecil dari 0,01 atau 0,05 maka Ho ditolak Ha diterima. Dengan demikian dapat disimpulkan bahwa ada pengaruh dan hubungan positif yang signifikan antara strategi pembelajaran guru dan sikap siswa terhadap efektivitas pembelajaran berbantuan internet.

Hasil pengujian regresi sederhana untuk mengetahui kontribusi masing-masing variabel independen $(\mathrm{X} 1, \mathrm{X} 2)$ terhadap variabel dependen (Y) maka diperoleh deskripsi/gambaran statistik disajikan pada tabel 7 dan 8 .

Dari tabel 7 dan 8 dapat dijelaskan bahwa variabel X1 memberikan pengaruh yang positif dan signifikan terhadap pembelajaran berbantuan internet. Koefisien korelasi antara variabel penguasaan strategi pembelajaran guru (X1) terhadap efektivitas pembelajaran berbantuan internet (Y) diperoleh koefisien korelasi sebesar 0,875 . hal ini menunjukan pengaruh positif diantara penguasaan strategi pembelajaran guru terhadap efektivitas pembelajaran berbantuan internet. Koefisien determinasi atau sumbangan efektif variabel penguasaan strategi pembelajaran guru terhadap efektivitas pembelajaran berbantuan internet adalah $76,6 \%$ yang berarti bahwa 23,4\% (100\% - 76,6\%) efektivitas pembelajaran ditentukan faktor lain. Sedangkan pada variabel X2 juga memberikan pengaruh yang positif dan signifikan terhadap pembelajaran berbantuan internet. Koefisien korelasi antara variabel sikap siswa (X2) terhadap efektivitas pembelajaran berbantuan internet (Y) diperoleh koefisien korelasi sebesar 0,901 . Hal ini menunjukan pengaruh positif diantara sikap siswa terhadap efektivitas pembelajaran berbantuan internet. Koefisien determinasi atau sumbangan efektif variabel sikap siswa terhadap efektivitas pembelajaran berbantuan internet adalah $81,2 \%$ yang berarti bahwa $18,8 \%(100 \%$ - 81,2\%) efektivitas pembelajaran ditentukan faktor lain.

Sedangkan hasil pengujian regresi ganda untuk mengetahui kontribusi variabel independen (X1 dan X2) terhadap variabel dependen (Y) maka diperoleh deskripsi/gambaran statistik disajikan pada tabel 9.

Hasil analisis dengan menggunakan regresi ganda antara penguasaan strategi pembelajaran guru (X1) dan sikap siswa (X2) terhadap efektivitas pembelajaran berbantuan internet (Y) diperoleh hasil R square sebesar 0,866, R 
square dapat disebut koefisien determinasi yang dalam hal ini berarti $86,6 \%$ kontribusi variabel penguasaan strategi pembelajaran guru dan sikap siswa terhadap efektivitas pembelajaran berbantuan internet. R square berkisar pada angka 0 sampai 1, dengan catatan semakin kecil angka $\mathrm{R}$ square, semakin lemah hubungan kedua variabel tersebut. Jadi, penguasaan strategi pembelajaran guru dan sikap siswa terhadap efektivitas pembelajaran berbantuan internet kontribusinya sebesar $86,6 \%$.

Penguasaan strategi pembelajaran guru dan sikap siswa merupakan faktor penting dalam meningkatkan efektivitas pembelajaran berbantuan internet, sehingga di duga sangat berpengaruh terhadap pembelajaran berbantuan internet di SMK Se-Kota Yogyakarta pada kompetensi teknik komputer dan jaringan.

\section{SIMPULAN DAN SARAN}

\section{Simpulan}

Hasil analisis penguasaan strategi pembelajaran guru di Sekolah Menengah Kejuruan (SMK) yang telah memanfaatkan pembelajaran internet memiliki rerata 150,52 berada pada kategori baik dengan persentase $53,29 \%$; dan terdapat pengaruh yang positif dan signifikan antara penguasaan strategi pembelajaran guru terhadap efektivitas pembelajaran berbantuan internet di SMK Se-Kota Yogyakarta.

Hasil analisis sikap siswa pada pembelajaran berbantuan internet di SMK yang telah memanfaatkan Internet memiliki rerata 62,95 berada pada kategori baik dengan persentase $54,31 \%$; dan terdapat pengaruh yang positif dan signifikan antara sikap siswa terhadap efektivitas pembelajaran berbantuan internet di SMK Se-Kota Yogyakarta.

Hasil analisis kualifikasi guru di SMK yang telah memanfaatkan internet memiliki rerata 23,4 berada pada kategori cukup dengan persentase $22,8 \%$.

Hasil analisis sarana dan prasarana di SMK yang telah memanfaatkan internet memiliki rerata 32,42 berada pada kategori sangat baik dengan persentase $85,71 \%$.

(a) Hasil analisis keefektifan pada pembelajaran berbantuan internet di SMK yang telah memanfaatkan Internet memiliki rerata 62,38 berada pada kategori baik dengan persentase $54,82 \%$; (b) Terdapat pengaruh yang positif dan signifikan antara penguasaan strategi pembelajaran guru dan sikap siswa terhadap efektivitas pembelajaran berbantuan internet di SMK Se-Kota Yogyakarta; (c) Hasil regresi ganda memberikan sumbangan efektif sebesar $86,6 \%$. Sumbangan efektif tersebut adalah strategi pembelajaran guru sebesar $76,6 \%$, sikap siswa sebesar $81,2 \%$.

\section{Saran}

Dengan kondisi kualifikasi guru yang berbeda-beda dan penguasaan strategi pembelajaran guru yang masih kurang sehingga perlu diadakan pelatihan-pelatihan yang berhubungan dengan pembelajaran internet bagi guru, dalam rangka meningkatkan penguasaan strategi pembelajaran guru

Penguasaan strategi pembelajaran guru, sikap siswa merupakan faktor yang berhubungan positif dan signifikan dengan keefektifan pembelajaran berbantuan internet di SMK SeKota Yogyakarta Sehingga diharapkan kepada pihak-pihak yang terkait dalam hal ini dinas pendidikan pemuda dan olahraga kota Yogyakarta untuk membuat kebijakan-kebijakan yang mendukung peningkatan pembelajaran berbantuan internet di SMK berupa pelatihanpelatihan dan seminar-seminar yang berhubungan dengan pembelajaran internet di SMK SeKota Yogyakarta, serta seminar-seminar motivasi tentang pembelajaran.

Kepada peneliti lainnya agar dapat melakukan pengembangan penelitian lanjutan dengan meneliti langsung proses pembelajaran dengan berbantuan internet dalam bentuk penelitian eksperimen atau penelitian tindakan kelas, sehingga data yang didapat dalam bentuk konkret.

\section{DAFTAR PUSTAKA}

Association of southeast Asian Nations. (2009). Roadmap for an ASEAN Community 2009-2015. Jakarta: ASEAN Secretariat.

Aunurrahman. (2008). Sikap siswa terhadap pembelajaran kimia. Diambil pada tanggal 10 Juli 2012 pukul 05.11, dari http:// 
berbagireferensi.blogspot.com/2010/02/ sikap-siswa-terhadap pembelajarankimia.html.

Azwar, S. (1995). Sikap manusia teori dan pengukurannya. Yogyakarta: Pustaka Pelajar.

Depdiknas. (2008). Peraturan pemerintah nomor 40 tahun 2005, tentang standar sarana dan prasarana sekolah menengah kejuruan/madrasah aliyah kejuruan (SMA/MAK)

. (2005). Peraturan pemerintah nomor 19 tahun 2005, tentang standar nasional pendidikan.

Dikdas.Kemdikbud. (2013). 18.000 Sekolah di Indonesia terkoneksi akses internet. Diambil pada tanggal 16 Agustus 2013 pukul 08.13 dari, http://dikdas.kemdikbud.go.id/content/berita/media/18000sekolah-di-indonesia-terkoneksi-aksesinternet.html

Eric \& Osep (2008). Learning strategy. Diambil pada tanggal 26 Juli 2012 pukul 07.15, dari http://ericdigests.org/2000-2/ learning.htm

Gable, R. K. (1993). Instrument development in the affective domain. New York: Springer Science+Business Media, LLC

Gilbert, \& Jones, M. G. (2001). E-learning is e-normous.Electric Perspectives, 26(3), 66-82.

Holmes, E. (2010). British qualification 2010. Great Britain: Kogan Page Limited

KBBI. (2013). Kualifikasi. Diambil pada tanggal 26 Januari 2013 pukul 19.45, dari http://kbbi.web.id/kualifikasi

Lilik Gani. (2009). Akses internet disekolah rendah. Diambil pada tanggal $10 \mathrm{Juli}$ 2012 dari, http://www.poskota.co.id/ berita-terkini/2009/07/20/akses-internet-di-sekolah-rendah.html
Miarso, Y. (2008). Peningkatan kualifikasi guru dalam perspektif teknologi pendidikan. Jurnal Pendidikan Penabur, 10, 66-76

Minarti, S. (2012). Manajemen sekolah. Yogyakarta: Ar-Ruzz Media

Mulyasa, E. (2012). Manajemen berbasis sekolah. Bandung: PT. Remaja Rosdakarya

Oskamp, S \& Schultz, P.W. (2005). Attitude and opinion. London: Lawrence Erlbaum Associates Publisher

Republika Online. (2013). 101 sekolah telah tersambung dengan indischool. Diambil pada tanggal 16 Agustus 2013 pukul 08.19 dari, http://www.republika.co.id/ berita/nasional/jawa-tengah-diy-nasional/13/05/02/mm6iv6-101-sekolah-didiy-telah-tersambung-indischool

Rosenberg, M. J. (2001). E-learning: Strategies for delivering knowledge in the digital age. New York: McGraw-Hill.

Sanjaya, W. (2006). Strategi pembelajaran berorentasi standar proses pendidikan. Jakarta: Kencana Prenadamedia Group

Schmeck, R. R. (1988). Learning strategies and learning style. New York: Springer Science+Business Media, LLC

Slavin, R.E. (2006). Educational psychology: theory and practice eighty. United States of America: Pearson Education, Inc

Sukardi. (2013). Metodologi penelitian pendidikan: kompetensi dan praktiknya. Jakarta: PT. Bumi aksara

Surjono, H. D. (2009). Pengantar e-learning dan penyiapan materi pembelajaran. Diambil pada tanggal 26 Juli 2012 dari, http://herman.elearning-jogja.org

Urdan, T. A., \& Weggen, C. C. (2000). Corporate e-learning: Exploring a new frontier. Retrieved 17 October 2005, from http://www.spectrainteractive.com/pdfs/ CorporateELearingHamrecht.pdf 